which would affect the relative amounts of synthesis of the various proteins.

Even more basically, it is difficult to predict what would be the effects of deletion or modification of, for example, the hordein gene. Could it be that glutamine and other amino acids would then accumulate to a point at which natural feedback mechanisms would take over and allow amino acid interconversions to occur in younger leaves and awns, or even in the seed itself, so that amino acid supply came to match more nearly the new requirements of the seed? From a knowledge of the complexity of most biological systems one would guess that some such regulatory mechanism as this would operate, but it is clear that we need much more knowledge about the physiology of amino acids during seed formation before we are able to offer a rationale for the breeding of high nutritive varieties.

I wish to thank Dr A. P. Sims for his helpful criticism of the manuscript.

\title{
REFERENCES
}

Bassham, J. A. \& Kirk, M. (1964). Biochim. biophys. Acta 9o, 553.

Bishop, L. R. (1928). F. Inst. Brewing 34, ror.

Carr, D. J. \& Pate, J. S. (1967). Symp. Soc. exp. Biol. 21, 459.

Chibnall, A. C. (1939). Protein Metabolism in the Plant. Yale: University Press.

Cocking, E. C. \& Yemm, E. W. (1961). New Phytol. 6o, 103.

Folkes, B. F., Willis, A. J. \& Yemm, E. W. (1952). New Phytol. 51, 317.

Folkes, B. F. \& Yemm, E. W. (1956). Biochem.7. 62, 4.

Folkes, B. F. \& Yemm, E. W. (1958). New Phytol. 57, 106.

Mason, T. G. \& Maskell, E. I. (1928). Ann. Bot. 42, 571.

Pate, J. S. (1966). Ann. Bot. N.S. 30, 93.

Pate, J. S. (1968). In Recent Aspects of Nitrogen Metabolism p. 219. [E. J. Hewitt and C. V. Cutting, editors.] London: Academic Press Inc.

Sims, A. P. \& Folkes, B. F. (1964). Proc. R. Soc. B r59, 479.

Sims, A. P., Folkes, B. F. \& Bussey, A. H. (I968). In Recent Aspects of Nitrogen Metabolism p. 9I. [E. J. Hewitt and C. V. Cutting, editors.] London: Academic Press Inc.

Urion, E. \& Golovtchenko, V. (1940). Bull. Soc. chim biol., Paris 22, 203.

Wallace, W. \& Pate, J. S. (1965). Ann. Bot. NS 29, 655.

Wallace, W. \& Pate, J. S. (1967). Ann. Bot. NS 3r, 2 I3.

Yemm, E. W. (1949). New Phytol. 48, 3 I5.

Yemm, E. W. \& Folkes, B. F. (1953). Biochem. F. 55, 700.

Yemm, E. W. \& Folkes, B. F. (1958). A. Rev. Pl. Physiol. 9, 245.

Yemm, E. W. \& Willis, A. J. (I956). New Phytol. 55, 229.

\section{The breeding of wheat and maize with improved nutritional value}

\author{
By V. A. Johnson, P. J. MAtTern and J. W. Schmidt, Agricultural Research Service, \\ US Department of Agriculture and Department of Agronomy, University of Nebraska, \\ Lincoln, Nebraska, USA
}

Cereal grains are a basic food for much of the world's population. They are equally important as animal feed in countries in which livestock is produced. All cereal grains lack the balance of essential amino acids needed for full utilization of their protein. The amino acid lysine is in the shortest supply in the cereals. 
Improvement of the nutritional quality of cereal protein, therefore, must begin with lysine.

Determinations of animal and human protein requirements assume carbohydrate availability to satisfy minimal energy needs. In the presence of inadequate carbohydrates, established protein values become relatively meaningless, because the body will utilize protein to satisfy its minimal energy requirements and it will not be used for tissue synthesis and growth. Since the cereals are an important source of calories for most people, continued improvement of their productivity must be recognized. In undernourished countries of the world, cereal protein improvement at the sacrifice of productivity would have limited net nutritional value.

\section{Opaque-2 and floury-2 in maize}

Discovery in 1963 of the effect of the opaque- 2 gene in maize on the amino acid composition of its protein (Mertz, Bates \& Nelson, 1964) demonstrated for the first time the opportunity to improve the nutritional quality of cereal protein by breeding. In ordinary maize the major portion of the protein is comprised of zein which is nearly devoid of lysine and tryptophan, and incapable of supporting growth in young animals (Osborne \& Mendel, 1914). Opaque-2 and floury-2 genes sharply reduce the zein content of maize endosperm and significantly increase the levels of both lysine and tryptophan because of increased levels of glutelin proteins.

Spectacular results have been achieved in feeding trials with opaque-2 maize. For young children its nutritional value has been demonstrated to approach that of skim milk (Bressani, I966). Children suffering from kwashiorkor, a severe protein deficiency disease, recovered when opaque-2 maize was utilized as their sole source of protein (Pradilla \& Harpstead, 1968). The nutritional superiority of opaque-2 was demonstrated in rats by Mertz, Veron, Bates \& Nelson (1965), in pigs by Cromwell, Pickett \& Beeson (1967), and in adult human beings by Clark, Allen, Meyers, Tuckett \& Yamamura (1967).

\section{Breeding challenge in maize.}

The full value of high-lysine maize will be realized only if the trait can be combined with improved levels of protein and high yield. This is the challenge confronting maize breeders today. It is estimated that $15 \%$ of good-quality protein in the diet would be adequate for most young growing animals and $12 \%$ would satisfy the needs of mature animals (Mertz, I 968 ). Normal maize hybrids seldom exceed $9 \%$ protein. Illinois high-protein maize containing $18-20 \%$ protein has been utilized as a source of high protein and has been combined with the opaque-2 and floury-2 genes. It lacks yield unfortunately. Maize germplasm is currently being searched for additional genes that will enhance protein level and amino acid composition.

Incorporation of high lysine and improved levels of protein with high yield may be difficult. In all cereals there tends to be an inverse relationship between grain yield and the protein content of the grain. A further obstacle arises from the association of opaque- 2 and floury-2 genes with soft textured low-density endosperm that reduces 
kernel weight as well as grain yield. Research at Illinois (Alexander, I966) and Purdue (Sreeramulu \& Bauman, I968) indicates that yield reductions associated with opaque-2 and floury-2 genes are a function of genetic background. Improved amino acid balance can be maintained in opaque- 2 or floury-2 types that have normal or near-normal kernel texture. The double recessive of these two mutants possesses a near-flinty texture. It appears highly probable that both yield and kernel density problems can be solved by the proper combinations of modifier genes. Extensive search for such modifiers is under way.

\section{Protein improvement in wheat}

Discovery of the effect of the opaque-2 gene in maize on the quality of its protein has triggered the search for genes with similar effects in other cereals. Only recently, it has been established that genes are present in barley which promote high protein and high lysine (A. Hagberg, Svalof, Sweden; personal communication). Sorghum and rice germplasm also are being searched.

The University of Nebraska, in co-operation with the Agricultural Research Service, USDA, and Agency for International Development, US Department of State, conducts a comprehensive research programme on the nutritional quality of wheat. The research encompasses investigation of protein content as well as protein quality. The World Collection of Wheats, maintained by ARS, USDA is being systematically analysed for protein and lysine differences. The seed samples analysed were produced in Arizona, USA.

The genetic basis of differences in wheat protein content is now well established (Haunold, Johnson \& Schmidt, I962; Johnson, Mattern \& Schmidt, I967; Johnson, Schmidt \& Mattern, 1968; Johnson, Schmidt, Mattern \& Haunold, I963; Stuber, Johnson \& Schmidt, I962). Nebraska-ARS research results indicate that increases of $2-3 \%$ actual protein are possible by breeding (Table 1 ).

Contribution of increased protein content to the nutritional value of cereals must be recognized. Note in Table 2 that $100 \mathrm{~g}$ of normal wheat at I $\mathrm{I} \cdot \mathrm{I} \%$ protein provide

Table I. Grain yield and protein content of high-protein experimental winter wheats and standard commercial varieties in Nebraska performance trials, 1968

\begin{tabular}{|c|c|c|c|c|}
\hline \multirow[b]{2}{*}{ Variety } & \multirow[b]{2}{*}{ C.I. or Sel, no. } & \multirow[b]{2}{*}{$\begin{array}{l}\text { Leaf rust } \\
\text { severity and } \\
\text { reaction* } \\
(\%)\end{array}$} & \multicolumn{2}{|c|}{ 4-station } \\
\hline & & & $\begin{array}{c}\text { Mean grain } \\
\text { yield } \\
\text { (kg/ha) }\end{array}$ & $\begin{array}{c}\text { Mean grain } \\
\text { protein content } \dagger \\
(\%)\end{array}$ \\
\hline Scout & I 3546 & $70 \mathrm{~S}$ & 3045 & II· 6 \\
\hline Gage & 13532 & $60 \mathrm{MS}$ & 2843 & $12 \cdot 6$ \\
\hline Lancer & 13547 & $60 \mathrm{~S}$ & 2843 & II 6 \\
\hline Atl $66-\mathrm{Cmn} \times \mathrm{Wrr}$ & 66553 & $5 \mathrm{R}$ & 3038 & $13 \cdot 4$ \\
\hline At1 $66-\mathrm{Cmn} \times \mathrm{Wrr}$ & 66551 & Io MR & 2964 & I $4 \cdot 1$ \\
\hline Atl $66 \times \mathrm{Cmn}$ & 65317 & $5 \mathrm{R}$ & 2856 & $\mathrm{I} 4 \cdot \mathrm{I}$ \\
\hline Atl $66 \times \mathrm{Wi}$ & 65320 & $5 \mathrm{R}$ & 2708 & $14: 3$ \\
\hline
\end{tabular}

${ }^{*} \mathrm{~S}=$ susceptible $; \mathrm{MS}=$ moderately susceptible; $\mathrm{R}=$ resistant; $\mathrm{MR}=$ moderately resistant. $\uparrow_{14} \%$ moisture basis. 
Table 2. Comparative essential amino acid composition of normal maize and wheat

\begin{tabular}{|c|c|c|c|c|}
\hline \multirow[b]{2}{*}{ Amino acid } & \multicolumn{2}{|c|}{$\begin{array}{c}\text { Maize } \\
(8.8 \% \text { protein })^{*}\end{array}$} & \multicolumn{2}{|c|}{$\begin{array}{c}\text { Wheat } \\
\text { (1 } 1.1 \% \text { protein }) *\end{array}$} \\
\hline & $\%$ of protein & g/roo g grain & $\%$ of protein & $\mathrm{g} / \mathrm{l} 00 \mathrm{~g}$ grain \\
\hline Lysine & $3 \cdot 0$ & 0.26 & $3 \cdot 0$ & 0.33 \\
\hline Isoleucine & $4 \cdot 2$ & 0.37 & 3.5 & 0.39 \\
\hline Leucine & $14 \cdot 6$ & $\mathbf{I} \cdot 28$ & $7 \cdot 0$ & 0.78 \\
\hline Methionine & $1 \cdot 3$ & O.I I I & $I \cdot 4$ & $0 \cdot 17$ \\
\hline Phenylalanine & 5.8 & 0.51 & 4.9 & 0.54 \\
\hline Threonine & $4 \cdot 1$ & 0.36 & 3.0 & 0.33 \\
\hline Valine & $5 \cdot 7$ & 0.50 & $4 \cdot 3$ & 0.48 \\
\hline Tryptophan & 0.7 & 0.06 & $1 \cdot 3$ & 0.14 \\
\hline
\end{tabular}

more of many essential amino acids than an equivalent weight of maize possessing $8.8 \%$ protein. When wheat with $17.2 \%$ protein is compared with opaque- 2 maize with $10.0 \%$ protein, $100 \mathrm{~g}$ of wheat grain provide more of all essential amino acids than does an equivalent quantity of opaque-2 maize (Table 3 ).

Table 3. Comparative essential amino acid composition of opaque-2 maize and high-protein wheat

\begin{tabular}{|c|c|c|c|c|}
\hline \multirow[b]{2}{*}{ Amino acid } & \multicolumn{2}{|c|}{$\begin{array}{l}\text { Opaque-2 maize } \\
(\text { I0.0\% protein)* }\end{array}$} & \multicolumn{2}{|c|}{$\begin{array}{l}\text { High-protein wheat } \\
(17.2 \% \text { protein })^{*}\end{array}$} \\
\hline & $\%$ of protein & $\mathrm{g} / 100 \mathrm{~g}$ grain & $\%$ of protein & $\mathrm{g} / \mathrm{I} 00 \mathrm{~g}$ grain \\
\hline Lysine & $4 \cdot 8$ & 0.48 & $2 \cdot 9$ & 0.49 \\
\hline Isoleucine & $3 \cdot 4$ & 0.34 & 37 & 0.64 \\
\hline Leucine & $9 \cdot \mathrm{I}$ & 0.91 & $7 \cdot 1$ & $I \cdot 22$ \\
\hline Methionine & $2 \cdot 1$ & 0.21 & $1 \cdot 6$ & 0.28 \\
\hline Phenylalanine & $4 \cdot 5$ & 0.45 & $5 \cdot 2$ & 0.87 \\
\hline Threonine & 4.0 & 0.40 & $3^{\circ} 0$ & 0.51 \\
\hline Valine & $5 \cdot 1$ & $0.5 \mathrm{I}$ & $4 \cdot 5$ & 0.77 \\
\hline Tryptophan & $1 \cdot 3$ & 0.13 & $I \cdot I$ & 0.19 \\
\hline
\end{tabular}

The FAO provisional amino acid pattern and a nitrogen intake of $6.65 \mathrm{~g}$ per day for an adult human weighing $70 \mathrm{~kg}$ (FAO/WHO, I965) were utilized to compute the weight of grain needed to provide minimal amounts of each essential amino acid. Grain weights for different categories of maize and wheat are contained in Table 4. Only $355 \mathrm{~g}$ of wheat with $17.2 \%$ protein would be required to provide man with his minimal amino acid requirements compared to $548 \mathrm{~g}$ ordinary wheat with $\mathrm{II} \cdot \mathrm{I} \%$ protein. Grain of ordinary maize in the amount of $967 \mathrm{~g}$ but only $5 \mathrm{I} 5 \mathrm{~g}$ of opaque-2 maize would be necessary to provide the required amounts of the essential amino acids.

Thirty-nine wheats from the World Collection with highest lysine values were compared with sixteen wheats possessing the highest protein content (Table 5). 
Table 4. Weight of grain needed to provide an adult human being weighing $70 \mathrm{~kg}$ with his minimal essential amino acid requirement

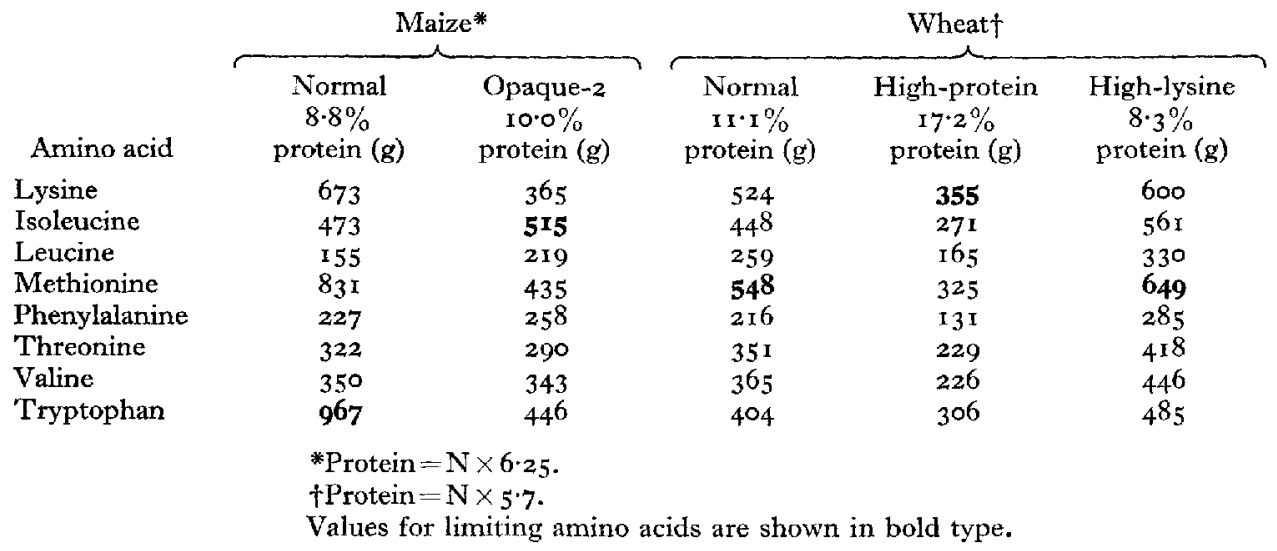

Table 5. Comparative essential amino acid composition of high-lysine wheats and high-protein wheats

\begin{tabular}{|c|c|c|c|c|}
\hline \multirow[b]{2}{*}{ Amino acid } & \multicolumn{2}{|c|}{$\begin{array}{l}\text { High-lysine wheats } \\
(8.3 \% \text { protein })^{*}\end{array}$} & \multicolumn{2}{|c|}{$\begin{array}{l}\text { High-protein wheats } \\
(17.2 \% \text { protein })^{*}\end{array}$} \\
\hline & $\%$ of protein & g/loo g grain & $\%$ of protein & $g / 100 \mathrm{~g}$ grain \\
\hline Lysine & $3 \cdot 6$ & 0.29 & $2 \cdot 9$ & 0.49 \\
\hline Isoleucine & 3.7 & 0.31 & $3 \cdot 7$ & 0.64 \\
\hline Ieucine & $7 \cdot 3$ & 0.61 & $7 \cdot \mathrm{I}$ & $I \cdot 22$ \\
\hline Methionine & $1 \cdot 7$ & 0.14 & $I \cdot 6$ & 0.28 \\
\hline Phenylalanine & $4 \cdot 9$ & 0.41 & $5 \cdot 2$ & 0.89 \\
\hline Threonine & 34 & 0.28 & $3 \cdot 0$ & $0.5 \mathrm{I}$ \\
\hline Valine & 4.7 & 0.39 & $4 \cdot 5$ & 0.77 \\
\hline Tryptophan & $1 \cdot 5$ & 0.12 & $I \cdot I$ & 0.19 \\
\hline
\end{tabular}

The high-protein wheats provided more of all essential amino acids per roo $\mathrm{g}$ of whole grain than did the high-lysine wheats.

We are seeking additional new genes for high protein in our programme. Such genes when combined with those from Atlas 66 could promote protein levels significantly higher than are now possible. The variety Aniversario from South America and the Nebraska fertility-restoring experimental line NB542437 appear to have high protein capabilities and may provide some of the sought-after genes.

High-protein genes from Atlas 66 need not adversely affect existing ratios of essential amino acids found in lower-protein commercially grown varieties (Table 6). The levels of three most critical essential amino acids in wheat, lysine, methionine, and threonine, were not adversely affected in some high-protein Atlas 66-derived Nebraska lines.

The strong influence of environment on the level of protein in wheat does not permit fixing protein at a specified level. Except under conditions of excessively 
Table 6. Lysine, methionine, and threonine levels in selected high-protein lines of Atlas $66 \times$ Comanche

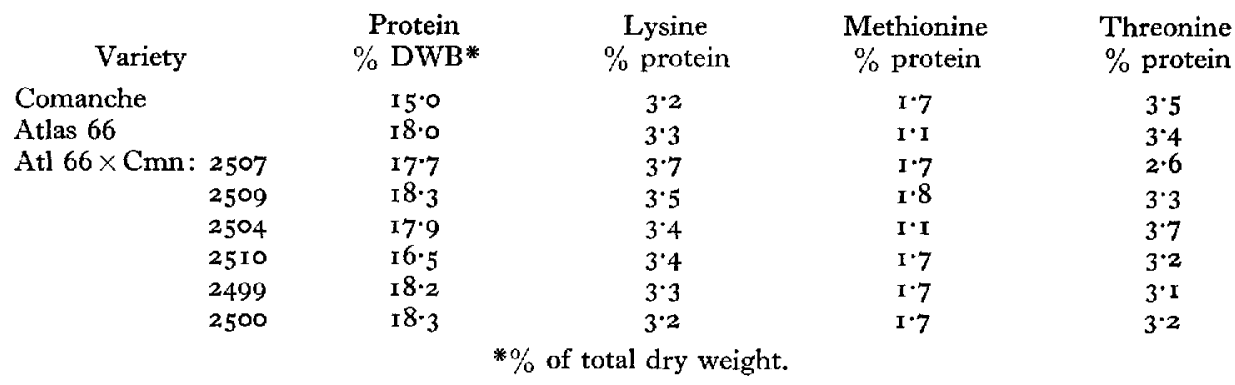

high soil nitrogen availability, high yields usually are associated with depressed protein content of the grain.

Genes that increase protein content must function in an array of environments and soil fertility levels to have maximum usefulness for nutritional improvement. Results of wheat performance trials in Nebraska (Table I) provide evidence that genes from Atlas 66 are effective in promoting high protein in productive varieties. Also, we demonstrated in 1968 that Atlas $66 \times$ Comanche Selection 65307 maintained its protein superiority over the Lancer variety over a range of soil fertility levels (Fig. I). The recent establishment of an International Winter Wheat Performance Nursery in which some high-protein wheats are being evaluated will provide additional valuable information on the stability and effectiveness of protein genes from Atlas 66.

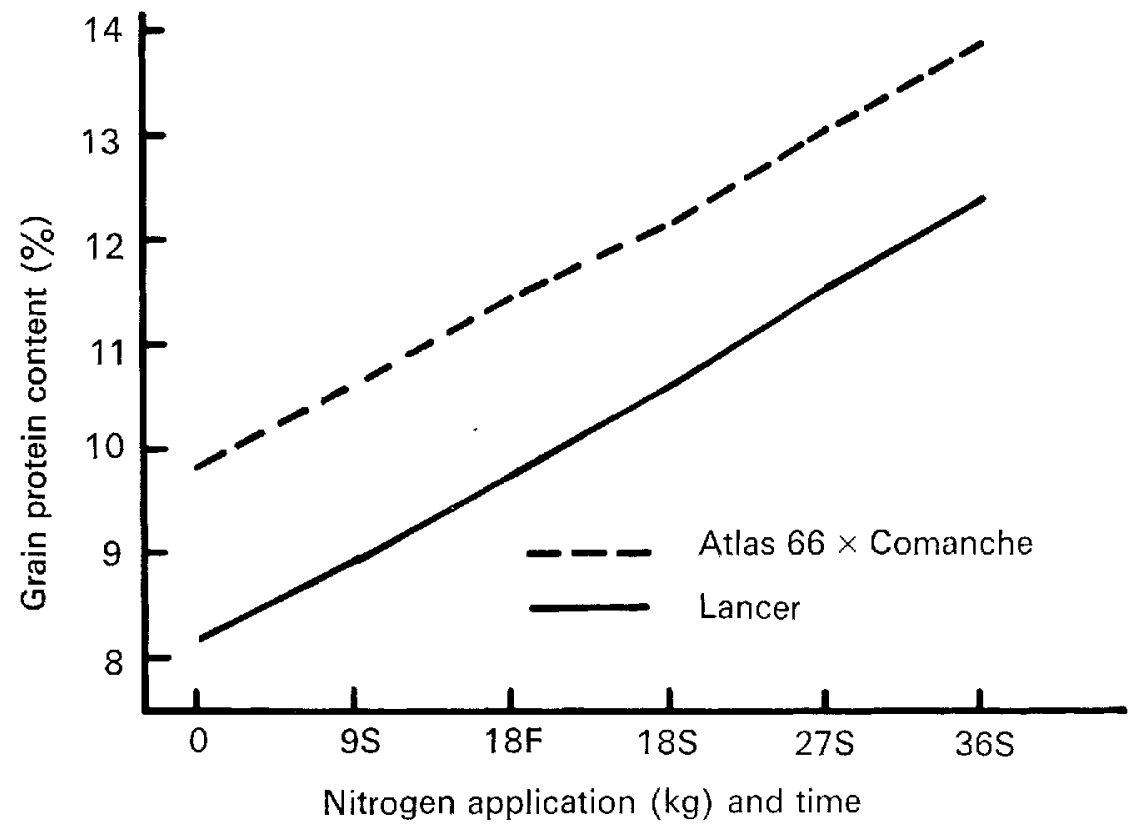

Fig. I. Grain protein content of Atlas $66 \times$ Comanche Sel. 65307 and Lancer wheat varieties produced under different levels of nitrogen fertilizer application in Nebraska, I968 (S $=$ spring; $F=$ fall). 


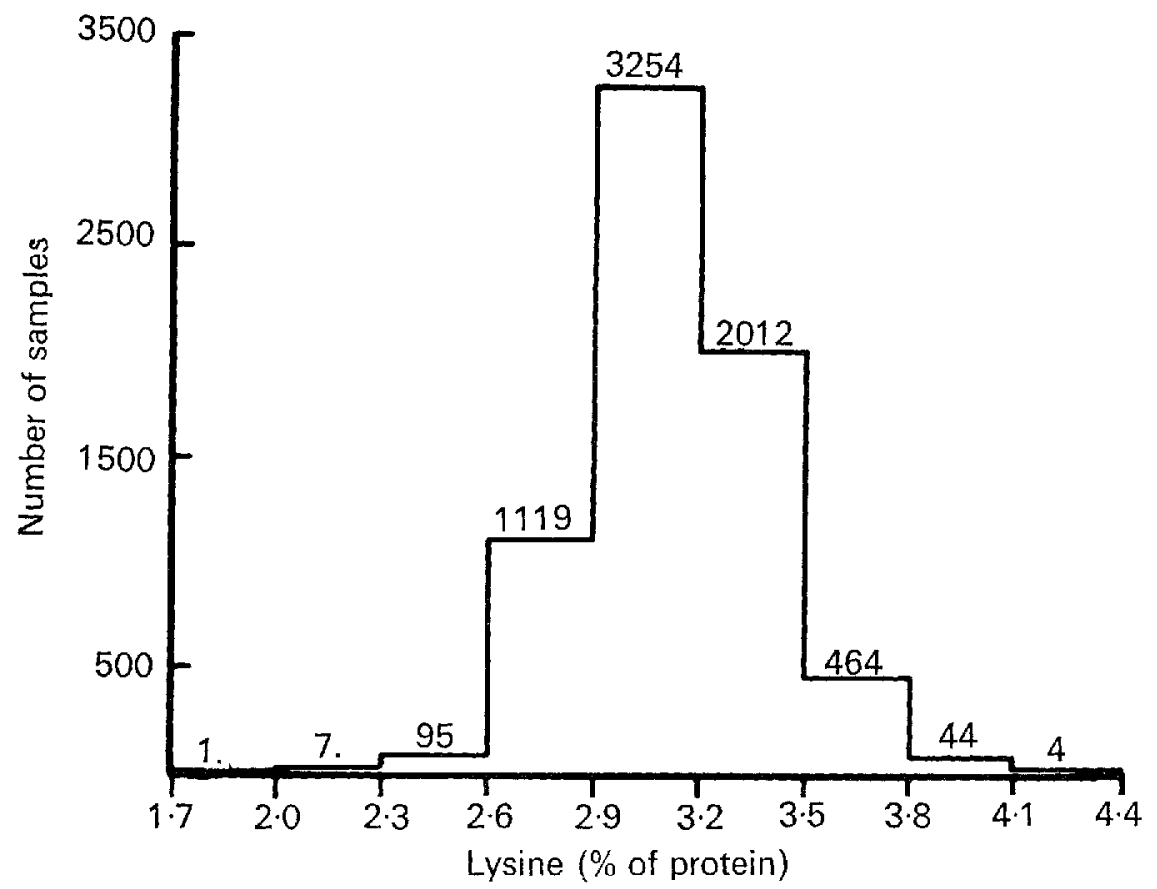

Fig. 2. Frequency distribution for lysine expressed as a percentage of protein; 7000 wheats from World Collection.

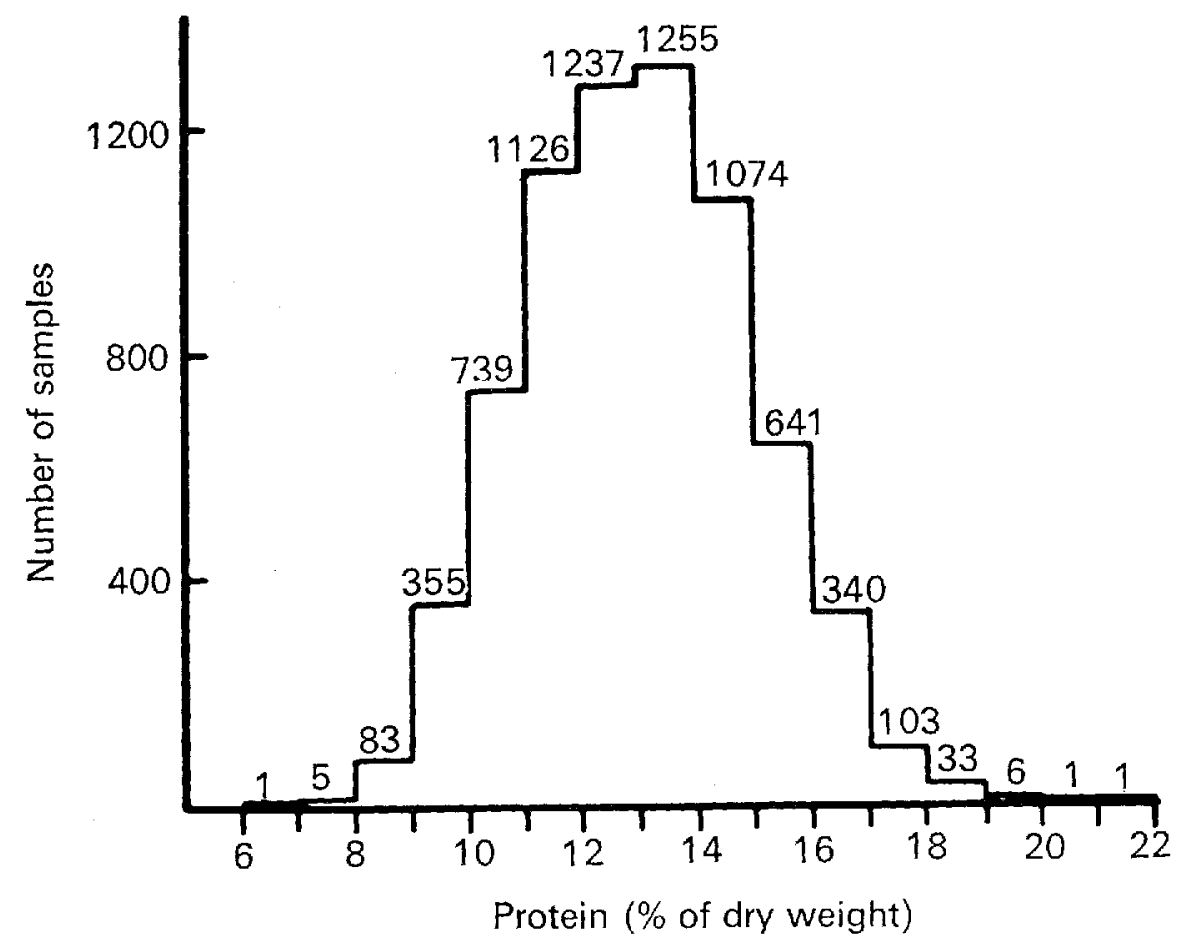

Fig. 3. Protein frequency distribution; 7000 wheats from World Collection. 
The search for high lysine in wheat

A gene in wheat with major effect on lysine such as that of opaque- 2 in maize, has not yet been identified. We have analysed more than 9000 wheats from the World Collection to date. Lysine values among these wheats ranged from $\mathrm{I} \cdot 7$ to $4.15 \%$ of protein (Fig. 2). Wide variations in protein were encountered. The protein frequency distribution is shown in Fig. 3. The degree to which the measured differences in protein and lysine are genetic has not yet been established. The strong influence of environment on protein level is already well established. Our findings suggest that a similarly strong environmental influence on amino acid composition of the protein also exists.

Lysine level in wheat tends to be negatively correlated with protein. We have recorded highest lysine values for wheats with lowest protein content. The negative regression of lysine (\% of protein) on protein among 7000 wheats from the World Collection is shown in Fig. 4. The shaded area indicates the range of dispersal of actual values about the regression line. Note that $40 \%$ of the variation in lysine could be attributed to variation in protein. We now utilize the regression coefficient to adjust lysine values to a common protein level. This provides a means of making lysine comparisons among wheat differing in protein content. The lysine frequency distribution of 7000 wheats after adjustment of lysine values to $13.5 \%$ protein

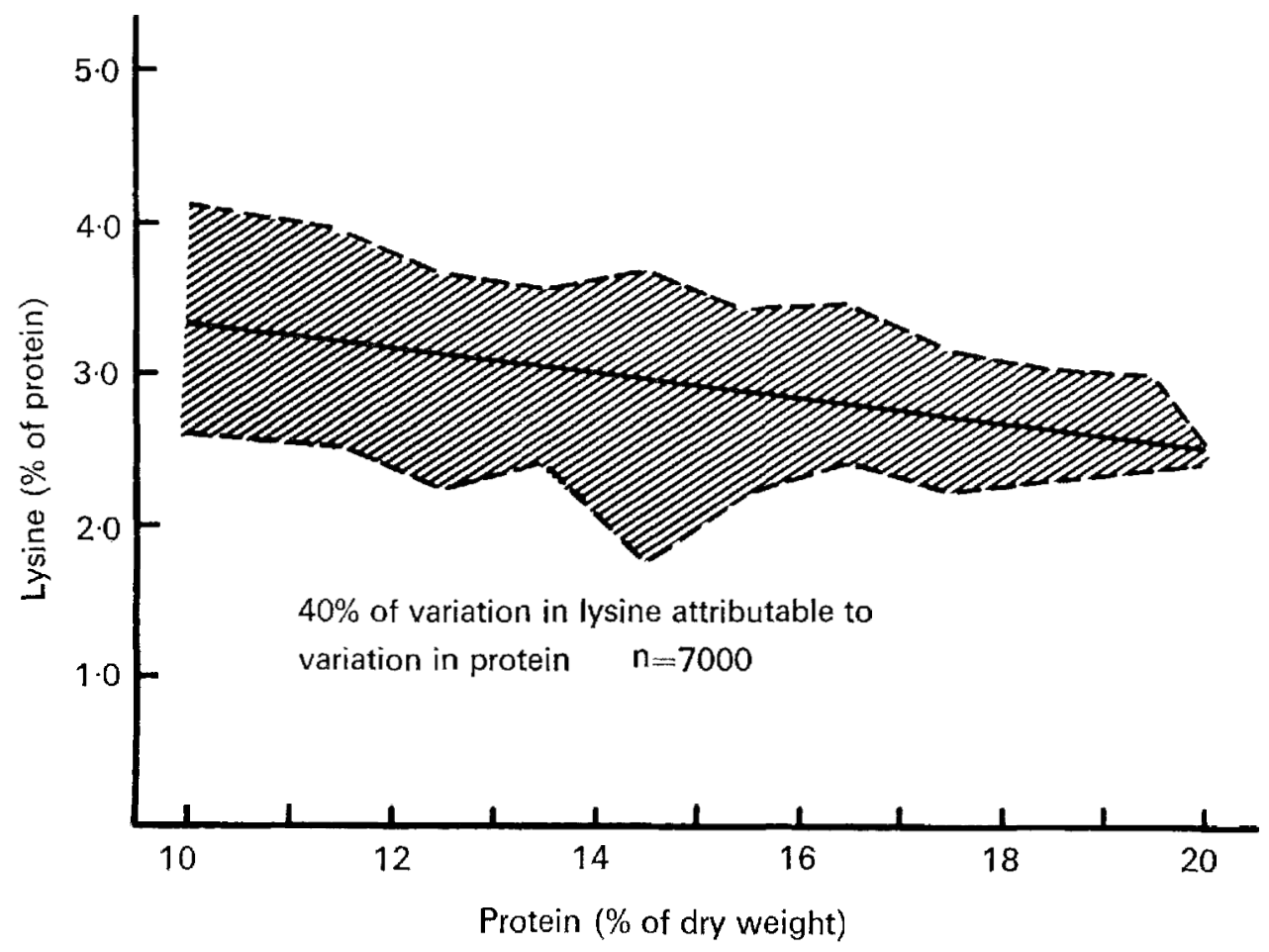

Fig. 4. Linear regression of lysine ( $\%$ of protein) on protein based on 7000 determinations from World Collection of wheats. 


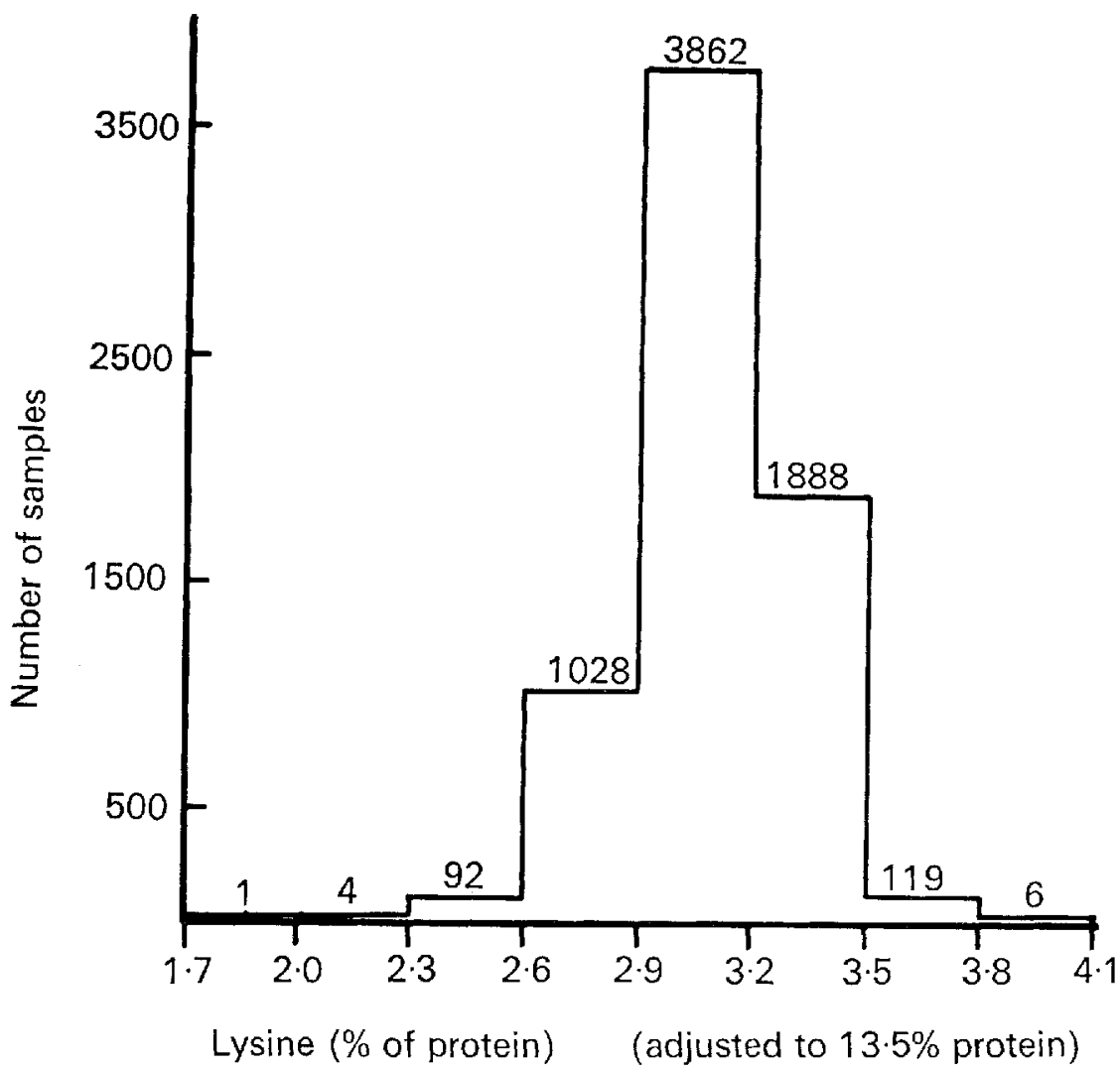

Fig. 5 Frequency distribution for lysine expressed as a percentage of protein (lysine values adjusted to $13.5 \%$ protein); 7000 wheats from World Collection.

is shown in Fig. 5. The number of wheats with adjusted lysine values higher than $3.5 \%$ is only 125 compared to $5 \mathrm{I} 2$ wheats with unadjusted values above $3.5 \%$.

Protein and lysine values of selected high-lysine wheats among the first 7000 analysed appear in Table 7 . The wheats are from seven different countries and

Table 7. Protein and lysine content of selected high-lysine wheats from the World Collection

\begin{tabular}{|c|c|c|c|c|c|}
\hline \multirow{2}{*}{$\begin{array}{c}\text { C.I. or P.I. } \\
\text { no. }\end{array}$} & \multirow[b]{2}{*}{ Origin } & \multirow{2}{*}{$\begin{array}{c}\text { Growth } \\
\text { habit }\end{array}$} & \multirow{2}{*}{$\begin{array}{c}\text { Protein } \\
\text { content }(\%)\end{array}$} & \multicolumn{2}{|c|}{ Lysine (\% of protein) } \\
\hline & & & & Unadjusted & Adjusted* \\
\hline I3449 & USA & Winter & $9 \cdot 2$ & $4 \cdot 15$ & $3 \cdot 9 \mathrm{I}$ \\
\hline 142509 & Iran & Winter & $9 \cdot 2$ & $4 \cdot 15$ & $3 \cdot 9 \mathrm{I}$ \\
\hline 11721 & Canada & Spring & $10 \cdot 2$ & 4.08 & 3.89 \\
\hline I 1696 & USA & Winter & II $\mathbf{I}$ & 3.97 & $3 \cdot 83$ \\
\hline I I $742 \mathrm{I}$ & Turkey & Spring & 777 & $4 \cdot 12$ & 3.80 \\
\hline 135073 & Afghanistan & Spring & $7 \cdot 5$ & 4.09 & $3 \cdot 76$ \\
\hline 121815 & India & Spring & $8 \cdot 1$ & 4.04 & 3.74 \\
\hline I I 2344 & England & Winter & $9 \cdot \mathbf{I}$ & 3.95 & $3 \cdot 70$ \\
\hline 13447 & USA & Winter & 10.3 & 3.87 & 3.69 \\
\hline ro9595 & Turkey & Spring & $9^{*} \mathrm{I}$ & 3.91 & 3.66 \\
\hline \multicolumn{2}{|c|}{ Mean (7000 wheats) } & - & $12 \cdot 9$ & $3 \cdot 12$ & 3.08 \\
\hline
\end{tabular}

*Values adjusted to $13.5 \%$ protein. 
Table 8. Parental relationships among high-lysine wheats

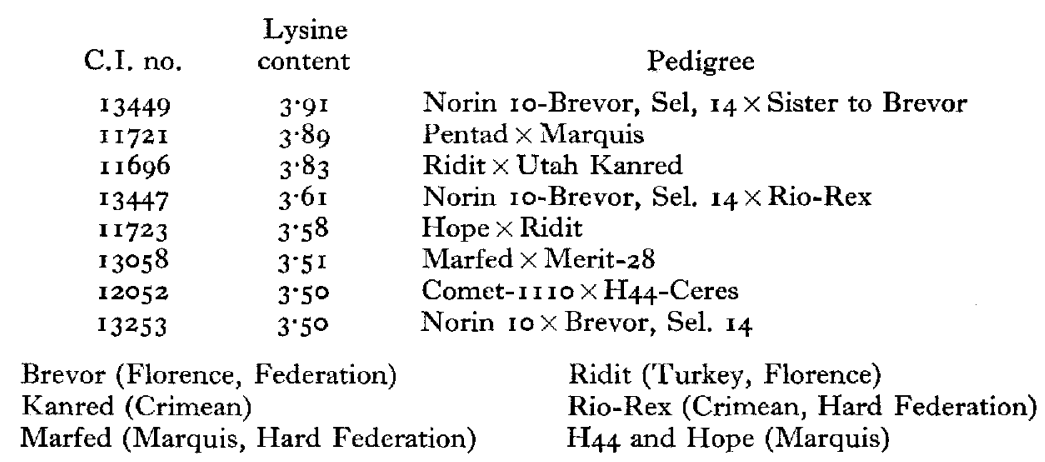

possess both spring and winter habits of growth. The protein levels of the wheats are low compared to the mean protein level of the 7000 wheats analysed. Therefore, adjustment of lysine values to $13.5 \%$ protein reduced the highest value from $4^{\cdot}$ I 5 to $3.91 \%$.

Pedigrees of some of the high-lysine varieties can be identified. They are shown for eight varieties in Table 8. Some possibly significant relationships emerge.

Table 9. Average effect of kernel size on the protein and lysine content of the grain of four wheat varieties

$\begin{array}{lccc}\quad & \text { Protein } & \text { Lysine/dry wt } & \text { Lysine/protein } \\ \quad \text { Kernel size } & (\%) & (\%) & (\%) \\ \text { Large (on sieve \#8) } & 12 \cdot 7 & 0 \cdot 38 & 3 \cdot 1 \\ \text { Medium (on sieve \#7) } & 12 \cdot 2 & 0 \cdot 3^{8} & 3 \cdot 2 \\ \text { Small (on sieve \#6) } & 12 \cdot 5 & 0 \cdot 38 & 3 \cdot 1\end{array}$

C.I. 13252 has the pedigree Norin $10 \times$ Brevor, Sel. I4. C.I. 13447 and C.I. $\times 3449$ are derivatives of Norin $10 \times$ Brevor, Sel. 14. Further examination of pedigrees reveals that the old Australian varieties Florence, Federation, and Hard Federation appear frequently. Marquis and Crimean also are in evidence. We believe that some of these wheats may be contributing genes for lysine.

Non-endosperm proteins are richest in lysine (over $4 \%$ ) whereas endosperm proteins are relatively poor in lysine (approximately $2 \%$ ). Differences in kernel morphology could alter the ratio of endosperm to non-endosperm proteins, thereby

Table 10. Average effect of kernel size and configuration on the protein and lysine content of the grain of four wheat varieties

\begin{tabular}{|c|c|c|c|c|c|}
\hline \multicolumn{3}{|c|}{ Kernel } & \multirow{2}{*}{$\begin{array}{l}\text { Protein } \\
(\%)\end{array}$} & \multirow{2}{*}{$\begin{array}{c}\text { Lysine/dry wt } \\
(\%)\end{array}$} & \multirow{2}{*}{$\begin{array}{c}\text { Lysine/protein } \\
(\%)\end{array}$} \\
\hline Size & Configuration & Crease & & & \\
\hline Large & Plump & Closed & $12: 0$ & 0.37 & 3.15 \\
\hline Large & Plump & Open & $12 \cdot 6$ & $0 \cdot 39$ & 3.13 \\
\hline Large & Wrinkled & - & 14.3 & 0.43 & 3.02 \\
\hline Small & Plump & Closed & $11 \cdot 8$ & 0.38 & $3 \cdot 3 \mathrm{I}$ \\
\hline Small & Plump & Open & 12.9 & 0.40 & 3.24 \\
\hline Small & Wrinkled & - & 15.4 & 0.37 & 3.04 \\
\hline
\end{tabular}

$29(\mathrm{I}) 3$ 
affecting the overall lysine content of the kernel. Kernel size of four varieties as established by passing the grain over appropriately sized sieves had no effect on either protein content or lysine level (Table 9). Kernel configuration determined by kernel plumpness and crease characteristics strongly affected the protein content of kernels but had little effect on lysine expressed as a percentage of protein ('Table to).

\section{Baking quality versus mutritional quality}

The nutritional improvement of wheat may not be entirely compatible with accepted Western standards of bread wheat quality. Lysine-rich non-endosperm proteins are largely eliminated from wheat flour in the milling process. Increases in the lysine content of these non-endosperm proteins then would contribute little to increased lysine content of high-grade wheat flour.

Further incompatibility of nutritional improvement with baking quality may exist in the endosperm proteins themselves. These can be divided into gluten proteins and water-and-salt soluble proteins. The water-salt-soluble proteins are high in lysine (over $4 \%$ ), whereas the gluten proteins are very low (less than $2 \%$ ). The ratio of water-soluble to gluten protein varies. Low-protein wheats usually have a higher percentage of water-soluble protein. This accounts for the tendency of low-protein wheats to have a higher percentage of lysine. Also, wheats that are high in the water-salt-soluble endosperm proteins tend to have soft texture and poor bread-wheat milling and baking properties.

It is important that the difference between nutritional quality and baking quality by Western standards be understood and appreciated. In those parts of the world where the whole grain of wheat is utilized for food, the site of the lysine-rich protein in the wheat kernel would be of little consequence. Increases in the quantity of any of the proteins or increases in their lysine content would significantly enhance the nutritional value of wheat. The greatest nutritional enhancement would derive from simultaneous increases in both.

Our research findings point to the opportunity for increasing the protein content of wheat by breeding. We are finding substantial differences in lysine values of wheats in the World Collection. Until the nature of the lysine differences is more fully assessed, we cannot project their contribution to the nutritional improvement of wheat.

Joint contribution of the Crops Research Division, Agricultural Research Service, US Department of Agriculture and the Agronomy Department, University of Nebraska, Lincoln, Nebraska. The research was supported partially by funds from the Agency for International Development, US Department of State, Washington, DC, and the Nebraska Wheat Development Division.

Authors are Research Agronomist (USDA) and Professor, University of Nebraska; Associate Professor; and Professor, respectively, University of Nebraska.

REFERENCES

Alexander, D. E. (1966). Proc. High Lysine Corn Conference (Corn Industries Research Foundation), Washington, DC p. I43. 
Bressani, R. (1966). Proc. High Lysine Corn Conference (Corn Industries Research Foundation), Washington, DC p. 34 .

Clark, H. E., Allen, P. E., Meyers, S. M., Tuckett, S. E. \& Yamamura, Y. (1967). Am. F. clin. Nutr. 20, 825 .

Cromwell, G. L., Pickett, R. A. \& Beeson, W. M. (1967). F. Anim. Sci. 26, I325.

FAO/WHO (1965). F.A.O. Nutr. mig Rep. Ser. no. 37; WHO tech. Rep. Ser. no. 3or.

Haunold, A., Johnson, V. A. \& Schmidt, J. W. (r962). Agron. F. 54, zo3.

Johnson, V. A., Mattern, P. J. \& Schmidt, J. W. (1967). Crop Sci. 7, 664.

Johnson, V. A., Schmidt, J. W. \& Mattern, P. J. (1968). Econ. Bot. 22, 16.

Johnson, V. A., Schmidt, J. W., Mattern, P. J. \& Haunold, A. (1963). Crop. Sci. 3, 7.

Mertz, E. 'T. (1968). Agric. Sci. Rev. Third Quarter, p. I.

Mertz, E. T., Bates, L. S. \& Nelson, O. E. (1964). Science, N.Y. 145, I701.

Mertz, E. T., Veron, O. A., Bates, L. S. \& Nelson, O. E. (1965). Science, N.Y. 148, 1741.

Osborne, T. B. \& Mendel, L. B. (I914). 7. biol. Chem. 17, 325.

Pradilla, A. \& Harpstead, D. (r g68). Data from Department of Pediatrics, Universidad del Valle, Cali, Colombia, South America.

Sreeramulu, C. \& Bauman, I. F. (1968). Proc. Am. Soc. Agron. New Orleans, La.

Stuber, C. W., Johnson, V. A. \& Schmidt, J. W. (1962). Crop Sci. 2, 506.

\section{The prospects of breeding barley, wheat and oats to meet special requirements in human and animal nutrition}

\section{By R. N. H. Whiтehouse, Plant Breeding Institute, Trumpington, Cambridge}

The attention given by cereal breeders in this country to the chemical composition of grain has been much less than that given to what may be called farmers' characters. Where it has been given, attention has been limited to a few fields, particularly those related to bread and beer, namely the milling and baking properties of wheat and the malting and brewing qualities of barley. Feeding value as a character has been largely neglected until recently and, indeed, grain for feeding purposes was often that which failed to meet the quality requirements of millers and maltsters. Some official encouragement was given to oat growers to promote the use of varieties low in husk or high in oil content, but farmers on the whole have preferred varieties with high total yield.

While this paper is primarily concerned with biological problems, it is worth mentioning that in a free society economic forces largely determine which varieties are grown. If price support is not forthcoming for grain of special chemical composition there is every likelihood that such varieties will be neglected by farmers. This is because the addition of chemical selection criteria limits the breeder's choice of both parental and hybrid material, with the result that he may fall behind in the race to produce varieties heading the yield list of those recommended for cultivation. It may not therefore be worth embarking on a i 5 -year research programme, however good the scientific prospects, if the product is doomed to economic failure.

\section{Plant breeding procedures}

In order to appreciate the problems facing the breeder who contemplates making changes in quality characters, it is necessary to understand the methods he may use. A breeding programme may conveniently be divided into a series of steps, the first 